\title{
FOREST AREA CHANGES THROUGHOUT THE YEARS IN BJE- LOVARSKO-BILOGORSKA COUNTY
}

\author{
Nikola Kranjčić1 ${ }^{*}$, Antonio Jaguljnjak ${ }^{1}$, Jurica Ivanušec ${ }^{1}$, Mihael Heček ${ }^{1}$ \\ ${ }^{1}$ University of Zagreb, Faculty of Geotechnics, Hallerova aleja 7, 42000 Varaždin, Croatia \\ *E-mail of corresponding author: nikola.kranjcic@gfv.unizg.hr
}

\begin{abstract}
The results of forest cover reduction were obtained using raster data and administrative borders for the Republic of Croatia. Examples are taken from other countries to compare the results and show the reduction of cover, both forest and agricultural. The first part of this paper describes the situation in the Republic of Croatia, where Ministry of Environmental Protection provided analysis. The condition of land cover in the Republic of Croatia is presented. The second part of this paper is a description of the task development process in the software package "QGIS". From adding CLC raster data to, the actions performed in the program that were performed until the results arrived. Finally, the interpretation of the obtained data and the conclusion follow.
\end{abstract}

Keywords: Corine Land Cover, QGIS, Bjelovarsko-bilogorska, Forest cover

\begin{tabular}{c}
\hline $\begin{array}{c}\text { Received: } 10.07 .2021 . / \text { Accepted: } 15.09 .2021 . \\
\text { Published online: 01.12.2021. }\end{array}$ \\
\hline $\begin{array}{c}\text { Professional paper } \\
\text { https://doi.org/10.37023/ee.8.1-2.7 }\end{array}$
\end{tabular}

\section{INTRODUCTION}

The topic of the paper is reduction of forest cover in Bjelovarsko-bilogorska county from 1990 to 2018. Be-tween 1990 and 2000, data analyses were processed for the several processes were processed in Europe. Urbanization was most noticeable in the Netherlands (2.1\% of the total land area), changes in agricultural intensification in Ireland (3.3\%), in the Czech Republic extensive agriculture (over 3.5\%), afforestation in Portugal (over 4\%), whitewashing forests in Portugal (over 3.5\%) and water bodies construction in the Netherlands and Slovakia (over 0.1\%). (Feranec, 2010) In Romania, the results indicate that almost $7.5 \mathrm{~km} 2$ of forests $(0.81 \%$ of the total forest area) were cutted during 1990-2000. And $5.7 \mathrm{~km} 2(1.06 \%)$ during 20002006. Percentages of afforested areas per administrative unit ranged between $0 \%$ and $83.8 \%$ during 1990 2000. and between $0 \%$ and 95.9\% during 2000-2006. (Petrişor, 2015) In Bulgaria, CORINE Land Cover changes in land cover for the peri-od 1990-2000 cover an area of 123,080 ha or 1.1\% of the country's territory. The most significant changes relate to the forest landscape (58\% of the total changed area). Afforested areas are about 10\% larger than de-forested forests. (Vatseva, 2006) In Slovakia, for the period from 1976 to 1992, a study of the identification and analysis of landscape changes was conducted. The result of the research was the creation of a database on changes in land cover in certain districts of Slovakia. Deforestation reduced the forest area by $8.6 \%$ of the total area of Snina district, extensive agriculture by $3.5 \%$ of the total area of Snina district and urbanization together with industrialization by 3.3\% of the total area of Dunajska Streda district, and these are the largest identified surface changes. (Feranec, 2002) In the United Kingdom, from 2006 to 2012 , land cover change affected al-most $60 \%$ more land than from 2000 to 2006 . A greater diversity of land cover change of 165 species was found in the period from 2006 to 2012 than 67 species in the period from 2000 to 2006 . The area of altered cover increased by over 21,000 ha or $11 \%$ but remained at around $1 \%$ of the total land area in the UK. (Cole, 2018)

Using Landsat data in west Africa in the period from 1975 to 1990, the change of land cover was studied. Dur-ing the period from 1975 to 1990 , the net annual rate of change of dense tree cover was estimated at $0.95 \%$, for other wooded land $-0.37 \%$ and very low for mosaic tree cover $-0.05 \%$. On the other hand, other vegetation cover increased annually by $0.70 \%$, most likely due to the expansion of agricultural land. (Vittek, 2014)

\section{CORINE LAND COVER (CLC)}

The CORINE program enables us to properly manage our nature and environment, and those who make decisions should be provided with an overview of existing knowledge and information that is up to date on changes in the characteristics of the biosphere. In this case, the three principles of the CORINE pro-gram (coordination of environmental information) are European:

- collect information on the state of the environment regarding certain topics that have priority for all members of the State Union, 
- coordinate the collection of data and the organization of information between the Member States or at international level,

- $\quad$ to ensure that the information is consistent, and that the data is compatible.

On 27. June 1985, on a proposal from the Commission, the Council adopted a decision on the CORINE program. This work program of the commission refers to an "experimental project to collect, coordinate and ensure the consistency of information on the state of the environment and natural resources in the Community" (Official Journal L 176, 6.7.1985). To establish community environmental policy, it is appropriate to assess the effects these policies and incorporate the environmental dimension into other policies, understanding the different features of the environment:

- condition of individual environments,

- geographical distribution and condition of natural areas,

- geographical distribution and abundance of wild fauna and flora,

- quality and abundance of water resources,

- $\quad$ soil cover structure and soil condition,

- quantities of toxic substances released into the environment,

- $\quad$ lists of natural hazards, etc.

The next goal is to gather all the numerous attempts made over the years at various levels (international, joint, national, and regional) to obtain as much information as possible about the environment and the way it has changed.

Two main types of complementary actions have been taken to meet the objectives of the program:

- devising procedures for the collection, standardization, and exchange of environmental data in EC Member States.

- creating a geographic information system to provide environmental information that is crucial in the preparation and implementation of community policies.

\section{CORINE LAND COVER (CROATIA)}

\subsection{CLC Cro 2000}

The result of the CORINE Land Cover Croatia project is a digital, up-to-date database on land cover according to the CORINE nomenclature, which is the same for the entire European Union. Mapping of land cover in the EU was launched in 1990, and mapping of land changes for 2000 and 2006. The project is funded by the Ministry of Environmental Protection, Physical Planning and Construction, and is also the Croatian national share in the European Environment Agency, which is entrusted with the use of the database. The aim of the project is to provide relevant and up-to-date environmental databases. The maintenance of the database has been carried out by the Environmental Protection Agency since 2005. In 2002, the creation of the CLC database for the years 2000, 1990, 1980 began. IMAGE 2000, 1990, 1980 are based on available satellite imagery, processing and represent a large database. This period was to show an assessment of changes as natural processes and development processes, but also those that were a consequence of the war in the $90 \mathrm{~s}$.

Two basic "CORINE" databases that are indivisible and derived from each other:

- IMAGE2000, IMAGE1990 and IMAGE1980: cover all activities related to the acquisition, orthorectification of satellite images (Landsat TM and ETM+), including the production of European and national mosaics (Kušan, 2010)

- $\quad$ CLC2000, CLC1990 and CLC1980: cover all activities related to the establishment of the CLC land cover inventory database based on IMAGE products and interpretation (detection) of changes (Kušan, 2010)

Experts from Europe, from the European Topic Center on Terrestrial Environment, had the basic task of ensuring coordination and implementation of the harmonization of project results at the level of all EU countries and others participating in the project. OIKON d.o.o. and GISDATA d.o.o. were responsible for CLC interpretation with the purpose of creating CLC databases and CLC databases of land cover changes using basic reference originals - satellite images (IMAGE1980, IMAGE1990 and IMAGE2000).

\subsection{CLC Cro 2006}

With the aim of creating a map and database of land cover CLC 2006, a project of updating the database and changes that occurred on the land cover from 2000 to 2006 with the project implementation period from 2007 to 2008 was implemented. The CLC 2006 Croatia project is part of a larger project "Implementation of CLC 2006 in the West Balkan Countries" coordinated by the European Environment Agency. In a smaller size, the technical specifications were improved compared to CLC 2000, only changes that took up more than 5 ha were mapped. Recent IMAGE 2006 images from IRS and SPOT satellites were used. Which as a result contributed to the improvement of the spatial resolution which went from 30 meters (Landsat 7) to 20 meters (SPOT). 


\subsection{Land cover in Croatia, examples}

For the territory of the Republic of Croatia, a map of land cover was prepared according to the CORINE methodology for the reference years: 1980, 1990, 2000 and 2006, based on these databases, the areas for each CORINE class were calculated (Table 1).

Table 1. State of land cover in the Republic of Croatia according to CORINE land use classes in databases for $1980,1990,2000$ and 2006 (area in ha)

\begin{tabular}{|c|c|c|c|c|c|}
\hline $\begin{array}{l}\text { CLC } \\
\text { Code }\end{array}$ & Class Name & CLC 1980. & CLC 1990. & CLC 2000. & CLC 2006. \\
\hline & & & & ha & \\
\hline 111 & Settlements ( $>80 \%$ built) & 524 & 524 & 550 & 550 \\
\hline 112 & Settlements ( $<80 \%$ built $)$ & 131722 & 134464 & 138791 & 139723 \\
\hline 121 & Industrial or commercial premises & 10565 & 10826 & 11292 & 11853 \\
\hline 122 & Roads with associated land & 797 & 847 & 1398 & 7482 \\
\hline 123 & Ports with associated land & 647 & 699 & 704 & 704 \\
\hline 124 & Airports with associated land & 2481 & 2527 & 2610 & 2610 \\
\hline 131 & Miners & 3451 & 3602 & 4380 & 4909 \\
\hline 132 & Landfills & 308 & 308 & 434 & 418 \\
\hline 133 & Construction site & 286 & 409 & 817 & 1562 \\
\hline 141 & City greenery & 1812 & 1812 & 1782 & 1724 \\
\hline 142 & Sports and recreational facilities & 5211 & 5632 & 5667 & 5917 \\
\hline 211 & Arable land & 385633 & 378430 & 368974 & 370262 \\
\hline 212 & Irrigated agricultural areas & 9443 & 9397 & 9821 & 9821 \\
\hline 221 & Vineyards & 28200 & 28193 & 28925 & 29055 \\
\hline 222 & Orchards & 9760 & 9410 & 9548 & 9574 \\
\hline 223 & Olive groves & 18759 & 18705 & 20223 & 20197 \\
\hline 231 & Mowing meadows and intensive pastures & 475815 & 477566 & 307296 & 298950 \\
\hline 242 & $\begin{array}{c}\text { Mosaic of different ways of agricultural } \\
\text { use }\end{array}$ & 1034844 & 1026779 & 1017238 & 1022051 \\
\hline 243 & $\begin{array}{l}\text { Agricultural areas with a significant } \\
\text { share of natural vegetation }\end{array}$ & 515282 & 510822 & 523509 & 524202 \\
\hline 311 & Deciduous forest & 1706194 & 1695356 & 1695495 & 1682078 \\
\hline 312 & Coniferous forest & 105473 & 102496 & 105702 & 102528 \\
\hline 313 & Mixed forest & 273533 & 275465 & 272522 & 271624 \\
\hline 321 & Natural grasslands & 77147 & 77103 & 252102 & 252781 \\
\hline 322 & Screams, cretes and low thickets & 6892 & 6916 & 4114 & 4421 \\
\hline 323 & Sclerophilic vegetation & 134541 & 138026 & 144450 & 143691 \\
\hline 324 & Forest succession (land in healing) & 567840 & 591160 & 579824 & 592532 \\
\hline 331 & Beaches, dunes, sands & 563 & 484 & 225 & 225 \\
\hline 332 & Bare surfaces & 12706 & 12714 & 11892 & 11892 \\
\hline 333 & Areas with sparse vegetation & 65329 & 63989 & 61061 & 60807 \\
\hline 334 & Burnt areas & 1333 & 1547 & 3271 & 395 \\
\hline 411 & Land marshes & 17861 & 17841 & 19014 & 18887 \\
\hline 421 & Salt marshes & 517 & 517 & 548 & 538 \\
\hline 422 & Salt pans & 522 & 522 & 524 & 524 \\
\hline 423 & Areas affected by tides & 48 & 48 & 48 & 48 \\
\hline 511 & Water liquids & 23779 & 23167 & 23961 & 23968 \\
\hline 512 & Stagnant waters & 27593 & 29636 & 29695 & 29918 \\
\hline 521 & Coastal lagoons & 45 & 45 & 44 & 44 \\
\hline \multirow[t]{3}{*}{523} & Sea & 3163423 & 3159469 & 3156321 & 3156305 \\
\hline & Total Land & 5657456 & 5657984 & 5658451 & 5658465 \\
\hline & Total Republic of Croatia & 8820879 & 8817453 & 8814772 & 8814770 \\
\hline
\end{tabular}


Table 2. State of land cover in the Republic of Croatia according to CORINE databases for 1980, 1990, 2000 and 2006 (area in ha)

\begin{tabular}{|c|c|c|c|c|c|}
\hline \multirow{2}{*}{$\begin{array}{c}\text { Label } \\
\text { categories }\end{array}$} & \multirow{2}{*}{ Rollup Name } & \multicolumn{4}{|c|}{ Surface (ha) } \\
\cline { 3 - 6 } & CLC 1980 & CLC 1990 & CLC 2000 & CLC 2006 \\
\hline 1a & Man-influenced surfaces & 157804 & 161650 & 168425 & 177452 \\
\hline $\mathrm{a}$ & $\begin{array}{c}\text { Arable land and permanent } \\
\text { plantations }\end{array}$ & 451795 & 444135 & 437491 & 438909 \\
\hline $\mathrm{2b}$ & Heterogeneous agricultural areas & 2025941 & 2015167 & 1848043 & 1845203 \\
\hline $3 \mathrm{a}$ & Forests and thickets & 2653543 & 2664477 & 2653543 & 2648762 \\
\hline $3 \mathrm{~b}$ & Shrub and grass vegetation & 298511 & 300779 & 477115 & 474212 \\
\hline $4 \mathrm{a}$ & Swamp & 18948 & 18928 & 20134 & 19997 \\
\hline $5 \mathrm{a}$ & Inland waters & 51417 & 52848 & 53700 & 53930 \\
\hline & altogether & 5657456 & 5657984 & 5658451 & 5658465 \\
\hline
\end{tabular}

The largest part of the land area in the Republic of Croatia is occupied by forests and thickets with a share of about $47 \%$. Heterogeneous agriculture decreased by 3.2\% between 1980 and 2006 . The following category by share is shrub and grass vegetation of $8.4 \%$ in 2006 . This group also includes natural grasslands, shrubs of vegetation and areas that were burned in summer fires. Areas where there were forests in the past are now occupied by bushy vegetation, and this is especially true for coastal areas. The following category is intensive agriculture, which occupies $7.8 \%$ of the total area of the Republic of Croatia in 2006, and other categories occupy a very small share. Figures 1 to 4 shows changes of landscape in Croatia from 1980 till 2006.

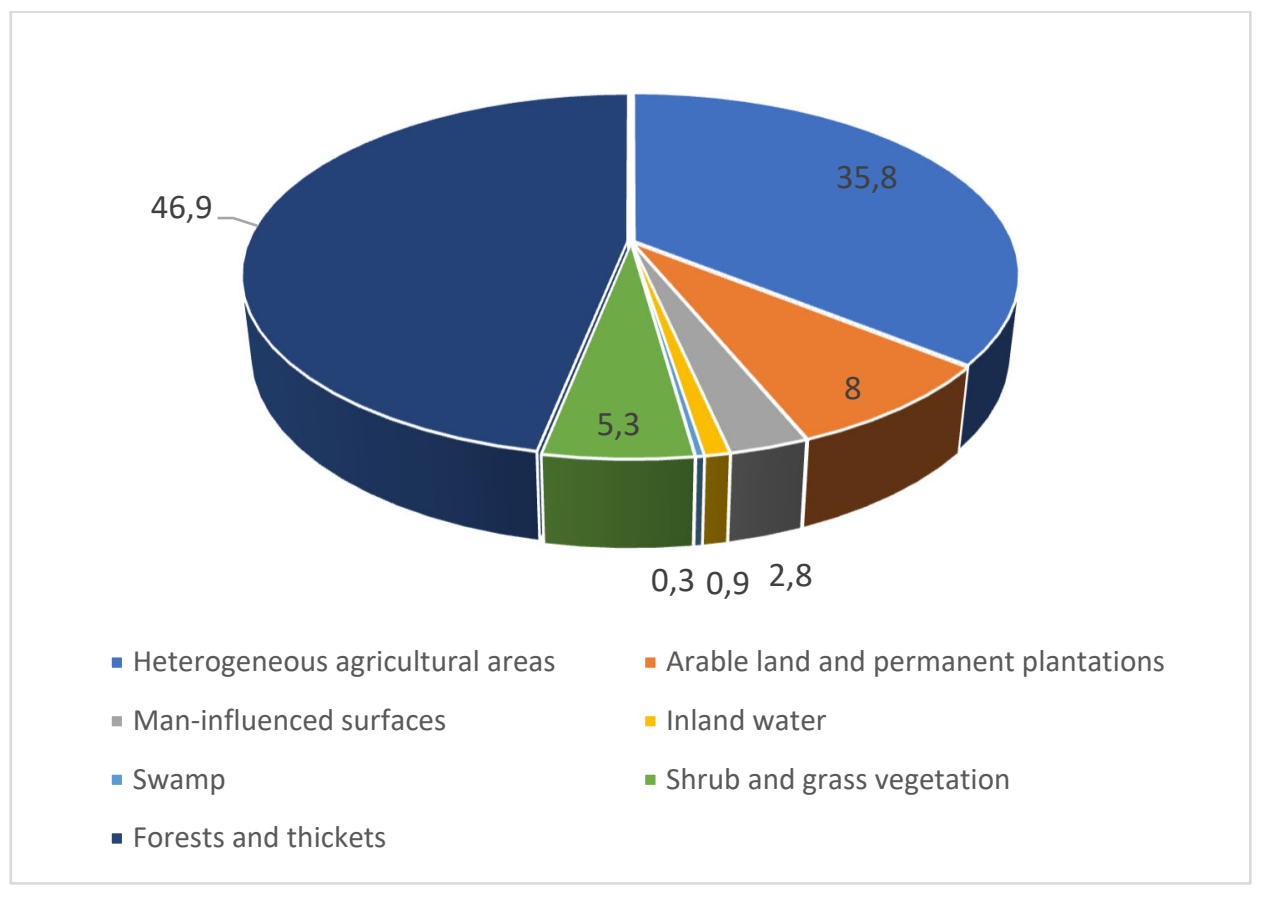

Figure 1. Structure of land cover by area in the Republic of Croatia (without sea) in 1980 


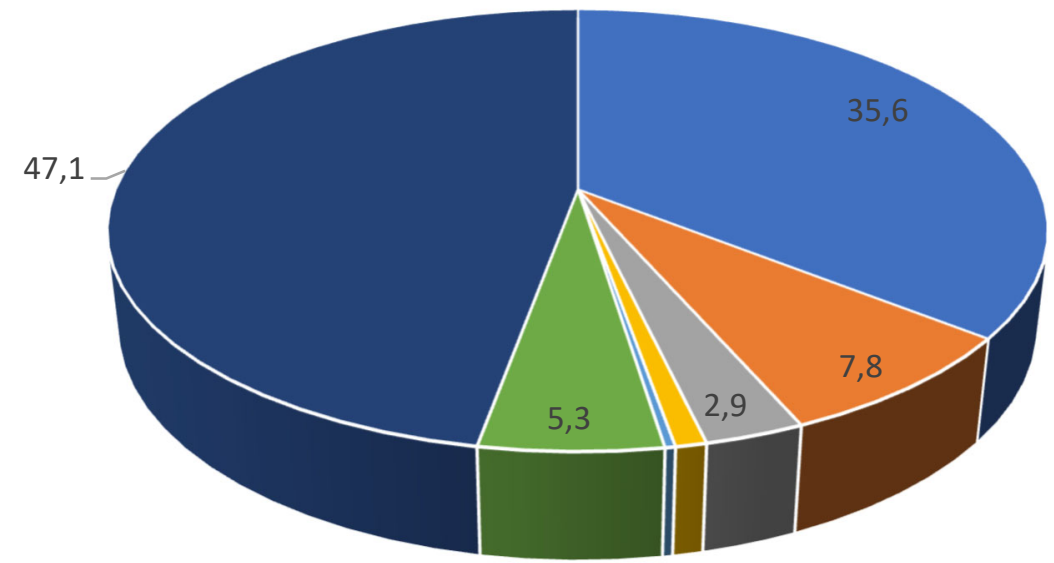

$0,30,9$

- Heterogeneous agricultural areas

- Man-influenced surfaces

- Swamp

- Forests and thickets
- Arable land and permanent plantations

- Inland water

- Shrub and grass vegetation

Figure 2. Structure of land cover by area in the Republic of Croatia (without sea) in 1990

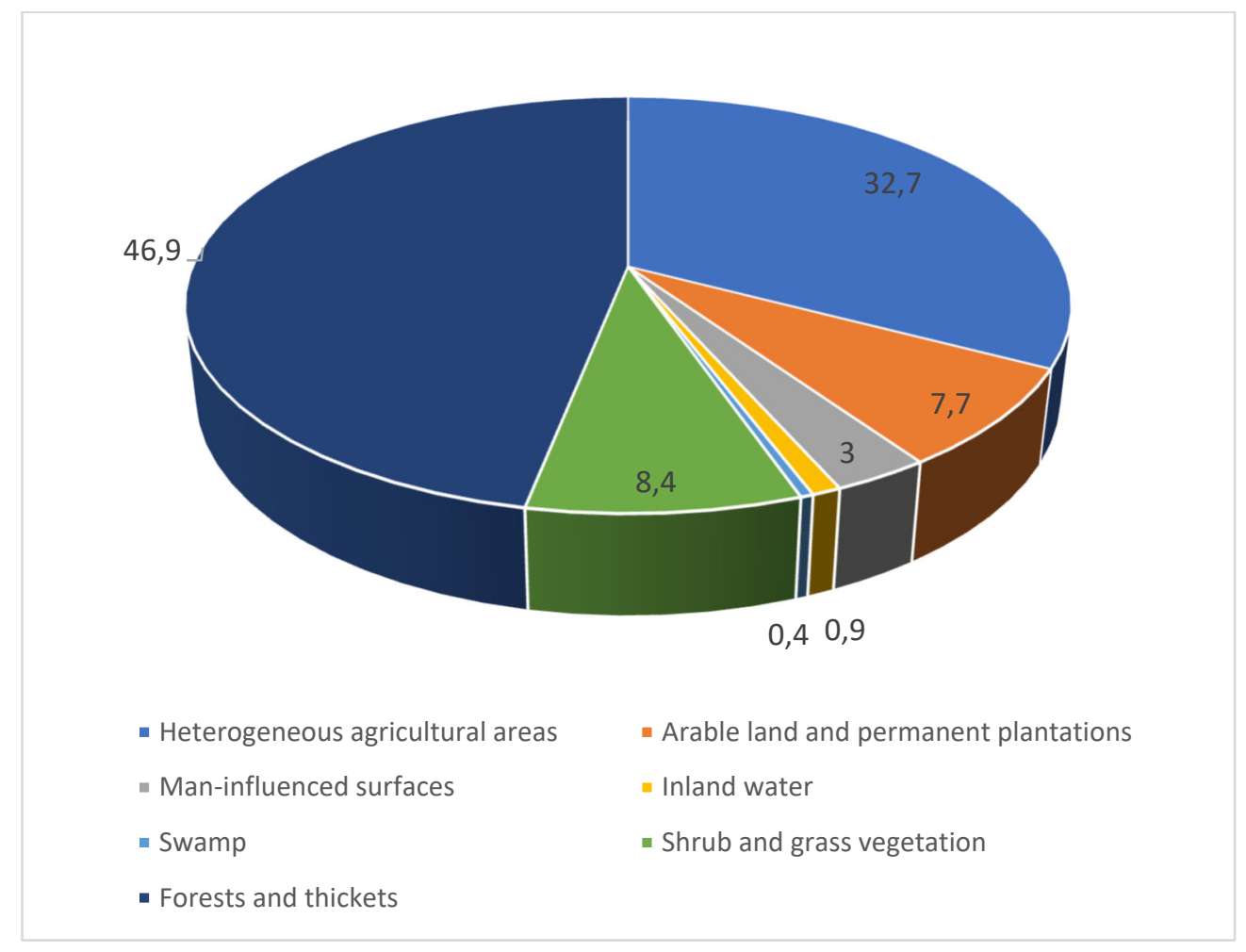

Figure 3. Structure of land cover by area in the Republic of Croatia (without sea) in 2000 


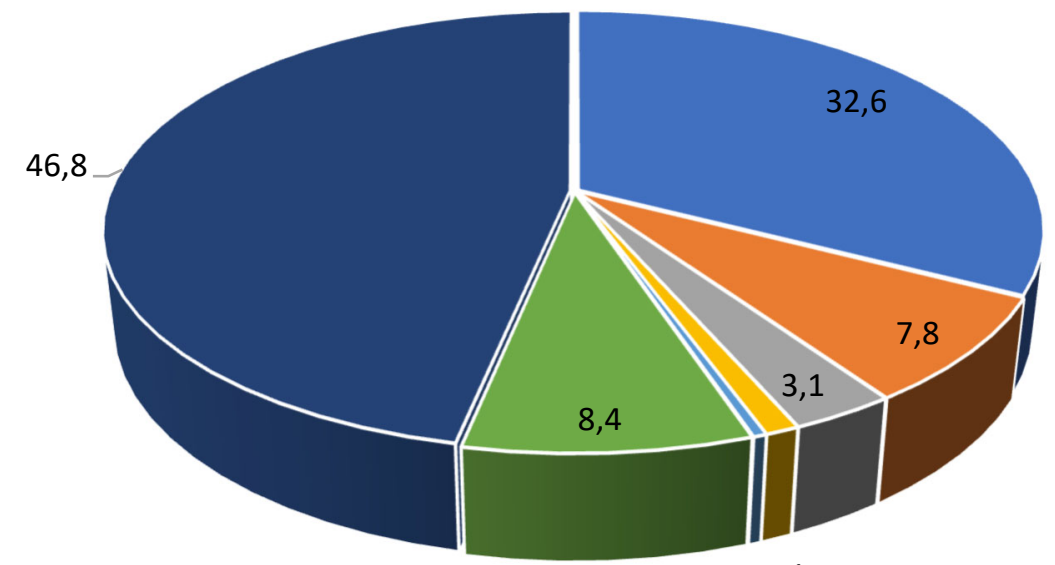

0,41

- Heterogeneous agricultural areas

- Man-influenced surfaces

- Swamp

- Forests and thickets
- Arable land and permanent plantations

- Inland water

- Shrub and grass vegetation

Figure 4. Structure of land cover by area in the Republic of Croatia (without sea) in 2006

Forests and thickets and heterogeneous agricultural areas are the categories in which the change in area is greatest, the reason being that these categories occupy the largest part of the land area of the Republic of Croatia with a share of about 80 percent. The change in forest and shrub areas in the first two periods amounted to more than 10,000 ha, and after that in the third period it amounted to 5,000 ha, due to the occurrence of neglect of agricultural land and forest management. Changes in heterogeneous agricultural areas are a consequence of the neglect of intensive agricultural areas. Due to human influence, large changes have occurred in the areas, because of the construction of infrastructure, urbanization. Arable land and permanent crops decreased until 2000, after which there was a gradual increase in their area.

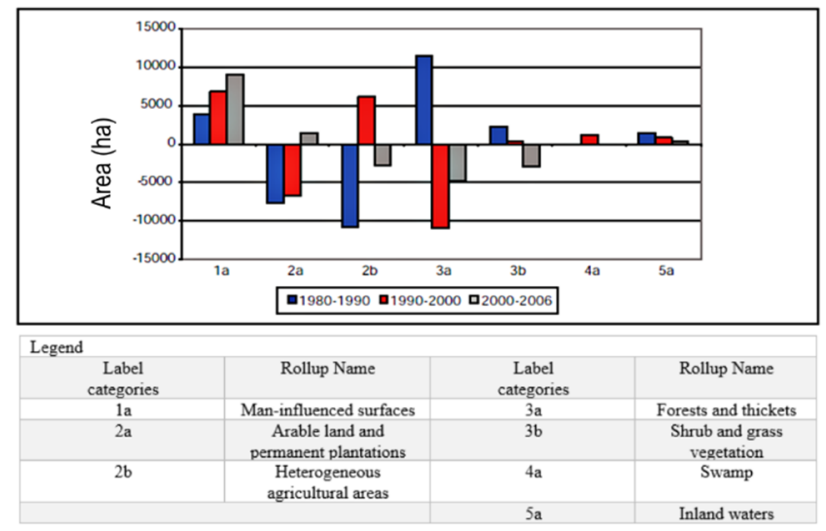

Figure 5. Differences in land use areas in the period 1980-2006.

\section{METHODOLOGY}

The first step is to download the raster data from the CORINE land cover website for each year separately (1990, 2000, 2006, 2012, 2018), and for the period between two years (1990.-2000., 2000.-2006., 2006.-2012., 2012.-2018.). We can notice that it is CLC raster data, while on the other hand for the period between two years there is CHA raster data. Each type of raster data is processed in the QGIS program in a different way, which will be described and explained in more detail below. After all the data for each year have been downloaded and unpacked, it is necessary to download the administrative boundaries, which is added as vector data. Let's open "QGIS Desktop with GRASS" and create a new document. First, we add the raster CLC data (TIFF image) that is 
in the downloaded DATA folder for each year separately (Figure 6). It should be noted that a separate document is prepared for each year in the QGIS to avoid confusion in the calculation of areas.

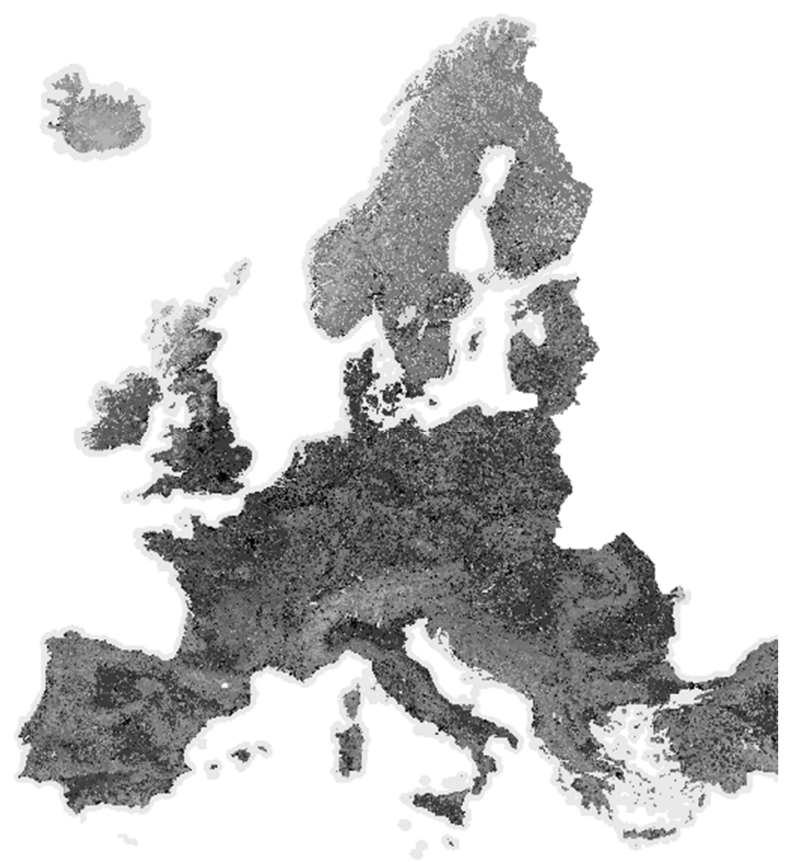

Figure 6. CORINE land cover layer

Furthermore, we add administrative boundaries for Croatia (SHP file) as vector data. After that vector data is filtered based on desired county to crop raster layer to be more suitable for processing. Figure 7 presents Bjelovarsko-bilogorska county on raster map.

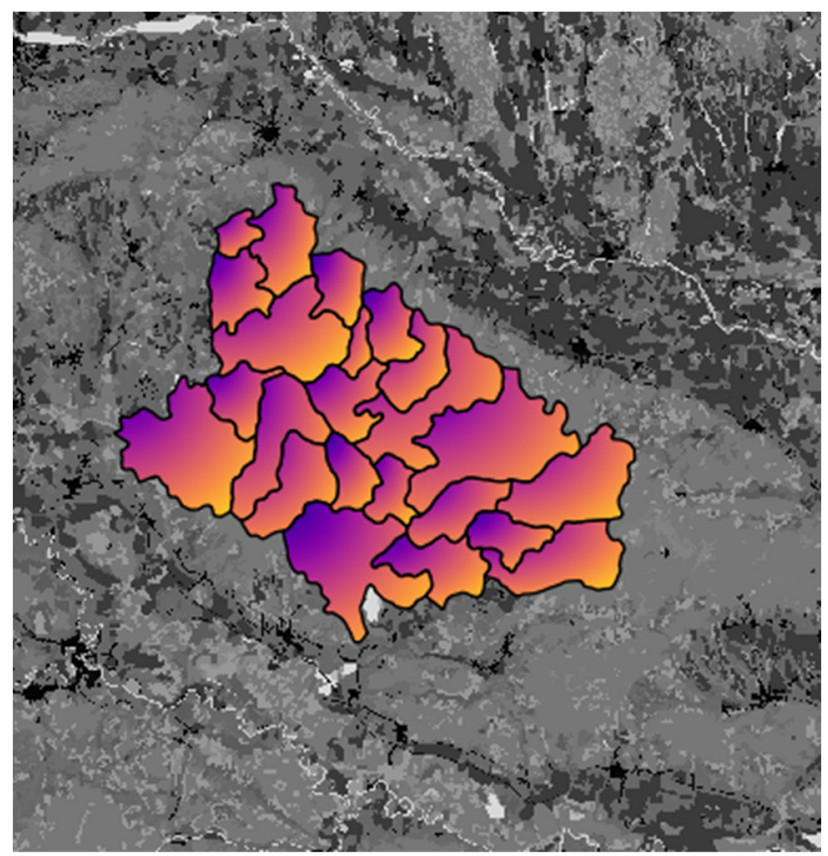

Figure 7. Separated county

After the raster is cropped there can be different selections performed. To establish connection between forest areas we chose dark green for the broadleaf forest, red for the coniferous, and orange for the mixed forest. Figure 8 presents only forest areas for selected county. 


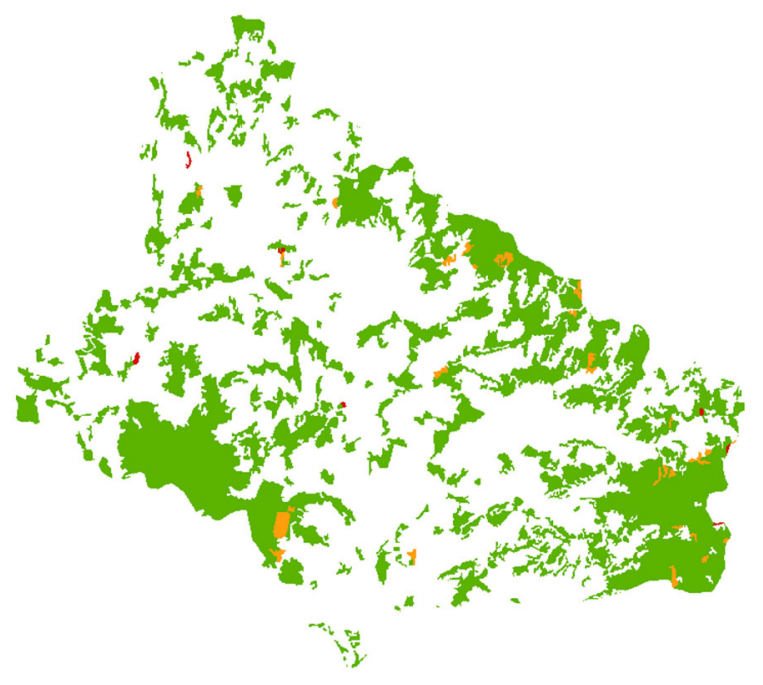

Figure 8. Forest areas for Bjelovarsko-bilogorska county

After forest areas have been filtered, it is necessary to calculate areas for each year, using raster report function. Figure 9 shows one raster report, where areas in square meters have been calculated.

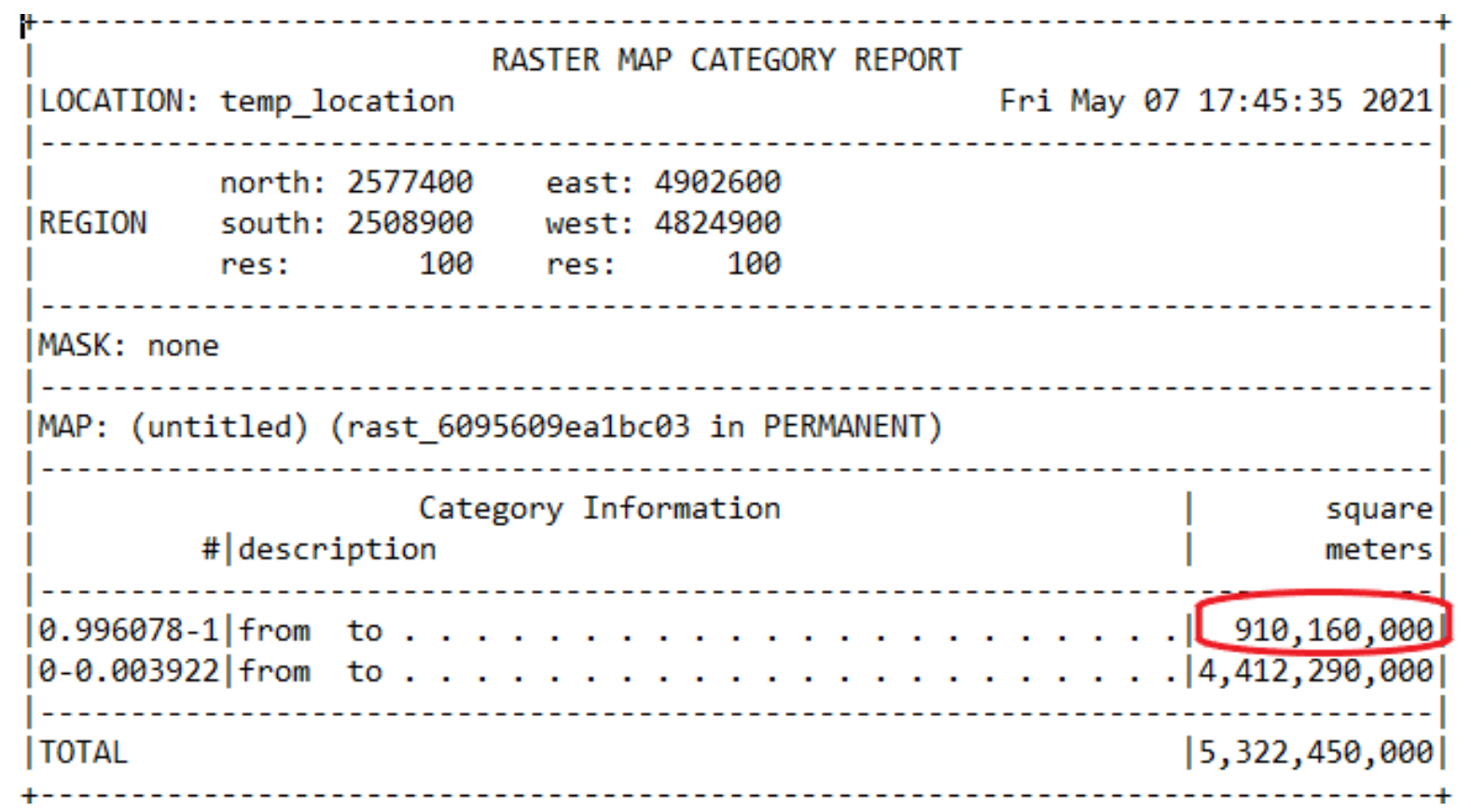

Figure 9. Raster map category report

In next section, there are graphical representation of forest areas for Bilogorsko-bjelovarska county. Table 3 presents forest areas and other surfaces for years 1990, 2000, 2006, 2012 and 2018.

Table 3. Total forest areas for different years

\begin{tabular}{|c|c|c|c|}
\hline Year & Forest area $\left(\mathrm{km}^{2}\right)$ & Other areas $\left(\mathrm{m}^{2}\right)$ & Total $\left(\mathrm{m}^{2}\right)$ \\
\hline 1990 & 879,83 & 4442,62 & 5322,45 \\
\hline 2000 & 884,61 & 4437,84 & 5322,45 \\
\hline 2006 & 885,80 & 4436,65 & 5322,45 \\
\hline 2012 & 910,16 & 4412,29 & 5322,45 \\
\hline 2018 & 890,01 & 4432,44 & 5322,45 \\
\hline
\end{tabular}


Based on the Table 3, we can see how the forest area of Bjelovarsko-bilogorska county has changed over the years, and the reasons for this can be numerous, from afforestation to logging etc. On Figure 10 changes in forest areas in $\mathrm{m}^{2}$ are presented.

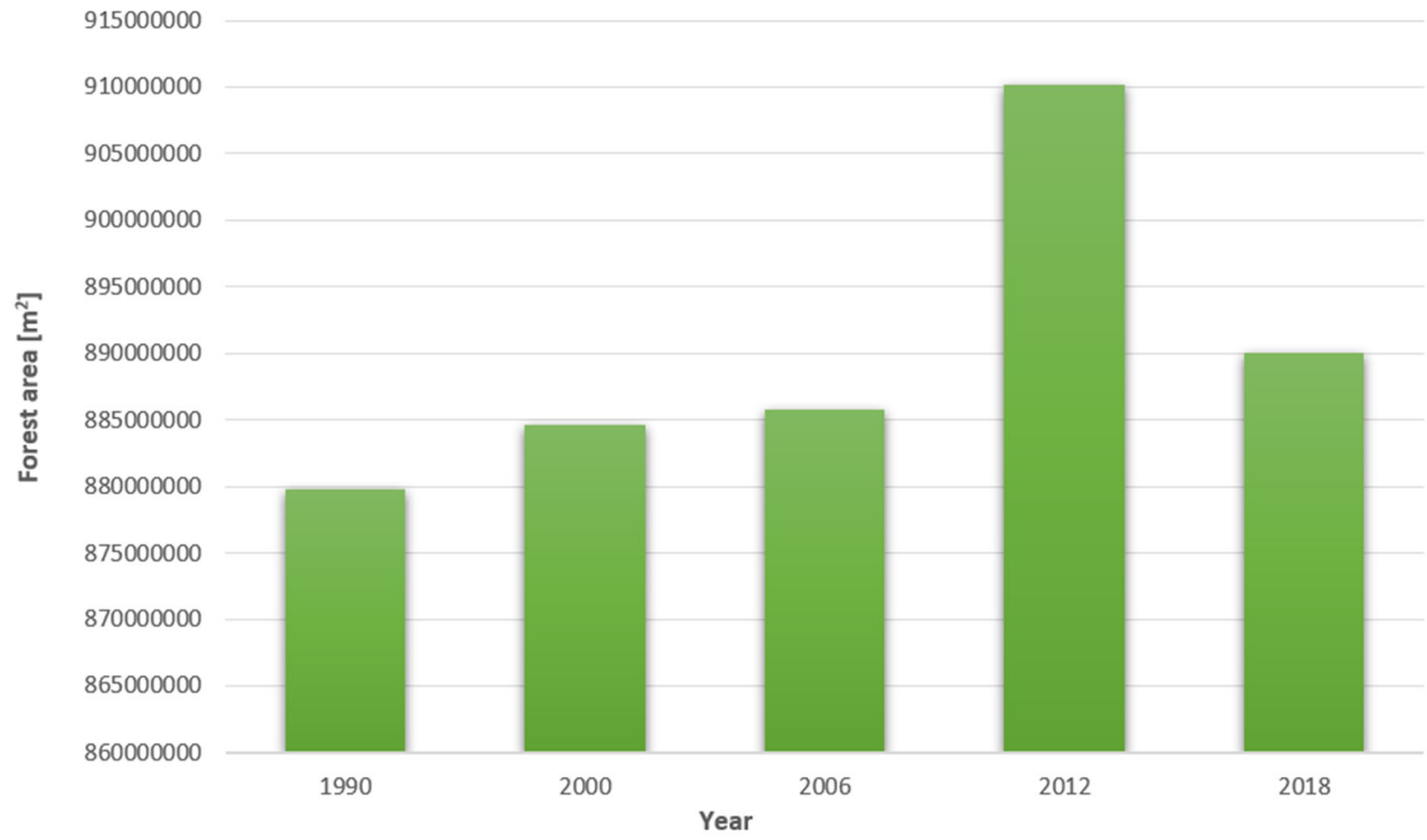

Figure 10. Forest area changes over the years in $\mathrm{m}^{2}$

In conclusion, we can observe that the forest area has increased with age which was not expected. From 2012 to 2018 , logging probably took place, but an increase in forest areas is still visible for a period of 28 years (Figure 11).

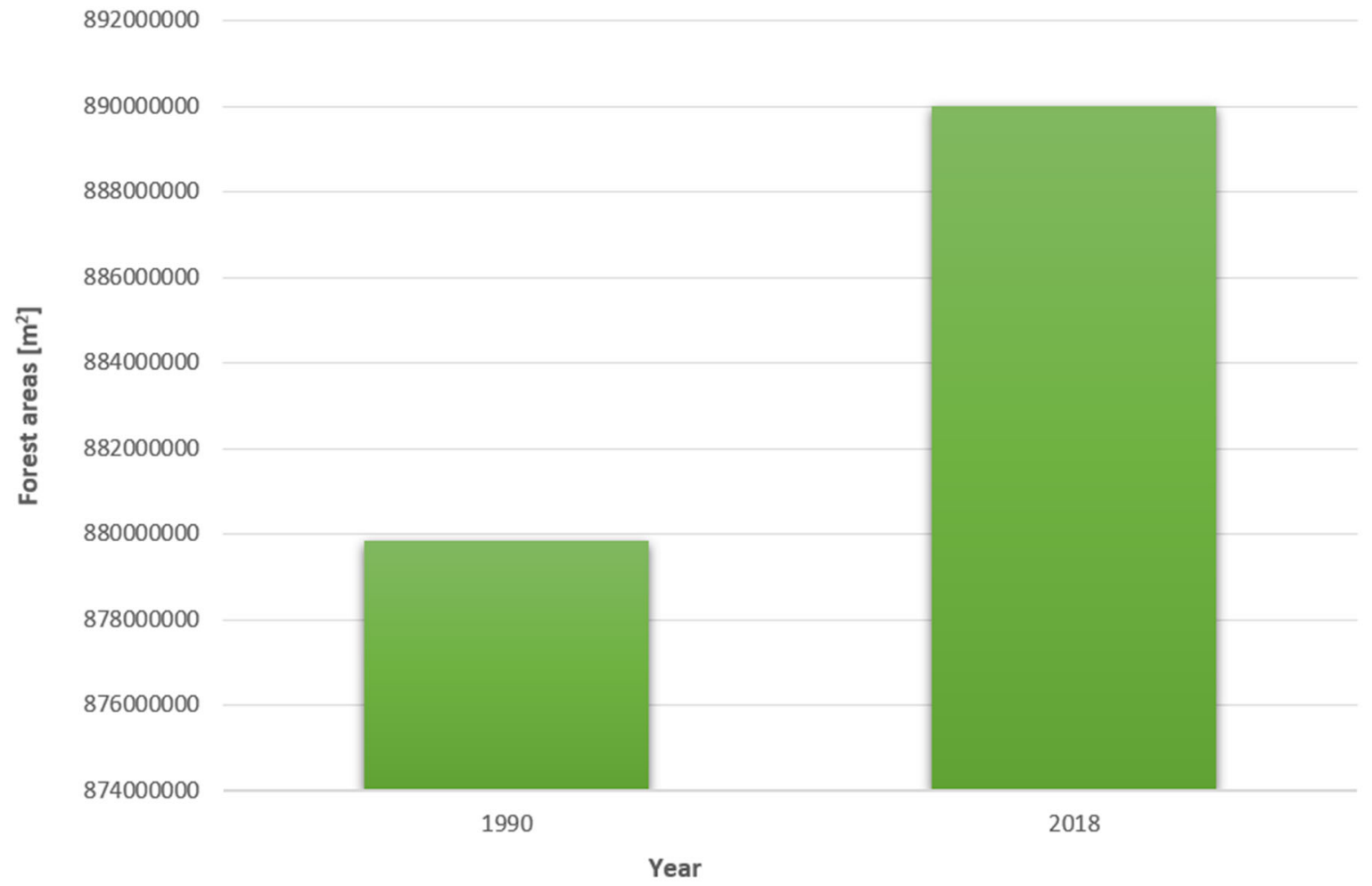

Figure 11. Forest areas difference from year 1990 to year 2018 in $\mathrm{m}^{2}$ 


\section{CONCLUSION}

Databases created according to the CORINE methodology, and their analysis have shown many advantages that these data provide. All data, for all periods, were obtained by the same methodology, are complete and processed with the same intensity in all parts of Europe, and the Republic of Croatia. The changes were mapped directly on satellite images, which enables the analysis of transitions of individual mapped classes and their tracking throughout the period. In this paper, an analysis of changes in forest cover in Bjelovar-Bilogora County is made. By working in the computer program "QGIS Desktop with GRASS" and processing the obtained raster CLC data, we obtained the results of the size of the areas covered with forest cover. There has been a noticeable increase in forest areas over the years. The increase was not expected, due to the trend of increasing deforestation in the world, but also in the Republic of Croatia. Only in the period from 2012 to 2018, the forest area was reduced, which is a direct result of logging. In general, in the period from 1990 to 2018, we can talk about an increase because of the overgrowing of some other areas, the expansion of forests and afforestation that took place in the Bjelovar-Bilogora County. Working in the program "QGIS Desktop with GRASS" gave us an insight into the situation in the field, without having to go to the field to record "manually" all the necessary data. Due to severe deforestation results presented in this paper are surprising. However, based on CORINE land cover data results are as presented. Increase in forest areas could be result of reduced agricultural areas and then shrubs and lower plants are labeled as forests. Further work should establish in detail changes in landscape.

\section{REFERENCES}

Cole, B. S. G. \&. B. H., 2018. Acceleration and fragmentation of CORINE land cover changes in the United Kingdom from 2006-2012 detected by Copernicus IMAGE2012 satellite data. s.l.:an.

Feranec, J. J. G. S. T. \&. H. G., 2010. Determining changes and flows in European landscapes 1990-2000 using CORINE land cover data. s.l.:an.

Feranec, J. S. M. C. T. \&. O. a. J., 2002. Methodological aspects of landscape changes detection and analysis in Slovakia applying the CORINE land cover databases. s.l.:an.

Kušan, V., 2010. Pokrov i namjena korištenja zemljišta u Republici Hrvatskoj-stanje i trendovi, s.l.: Agencija za zaštitu okoliša.

Petrişor, A. I., 2015. Using CORINE data to look at deforestation in Romania: Distribution \& possible consequences. INCD URBAN-INCERC.

Vatseva, R. \&. S. A., 2006. Spatial analysis of land cover and land use changes in Bulgaria for the period 19902000 based on image and CORINE land cover data. s.l.:an.

Vittek, M. B. A. D. F. S. D. \&. D. B., 2014. Land cover change monitoring using Landsat MSS/TM satellite image data over West Africa between 1975 and 1990. s.l.:an. 